\title{
The Performance of Banks in Indonesia Based on Capital Perspective (BUKU), a case Study in a period of Decline in Profitability Performance
}

\author{
Taufiq Akbar
}

Faculty of Economics and Business, Perbanas Institute, Jakarta, Indonesia

\begin{abstract}
This study aims to analyze and obtain empirical evidence regarding the effect of LDR on bank's profitability, and the variables that can moderate the influence of LDR on ROA. The object of this research is banks listed on the Indonesia Stock Exchange for the period of 2013 to 2016. 25 banks were selected using the purposive sampling method. The research object was divided into two categories, namely BUKU 1 and BUKU 2 banks, and BUKU 3 and BUKU 4 banks. The results showed that BUKU 1 and BUKU 2 banks were influenced by LDR and BI rate. Then, it moderated by OEOI. The study does not support the hypothesis that the NPL and NIM of BUKU 1 and BUKU 2 banks can moderate the influence of the LDR variable on ROA. While the influence of LDR on ROA of BUKU 3 and BUKU 4 banks was moderated by NIM and OEOI. The study does not support the hypothesis that the NPL of BUKU 3 and BUKU 4 banks can moderate the influence of the LDR variable on ROA.This study also supports the statement that the BI rate gives more influence to BUKU 1 and BUKU 2 banks than banks in the BUKU 3 and BUKU 4 categories.
\end{abstract}

Keywords: Declining Profitability, Bank Capital Perspective, Bank Performance Measurement.

\section{INTRODUCTION}

Bank Indonesia is an authority in Indonesia which aims to achieve and maintain the stability of the rupiah. In order to achieve these objectives, Bank Indonesia implemented three activities, namely establishing and implementing monetary policy, regulating and maintaining the smooth payment system, and regulating and supervising banks in Indonesia. Banks are regulated institutions. Where, every bank activity must follow the regulations set by Bank Indonesia. But like other companies, banks are organizations that aim to make a profit.

Profitability is a performance measurement used to see the success of a bank's financial performance. However, in 2012 to 2016 the average profitability performance did not show good performance. As illustrated in figure 1 below:

Figure 1: ROA Performance of Banks in Indonesia

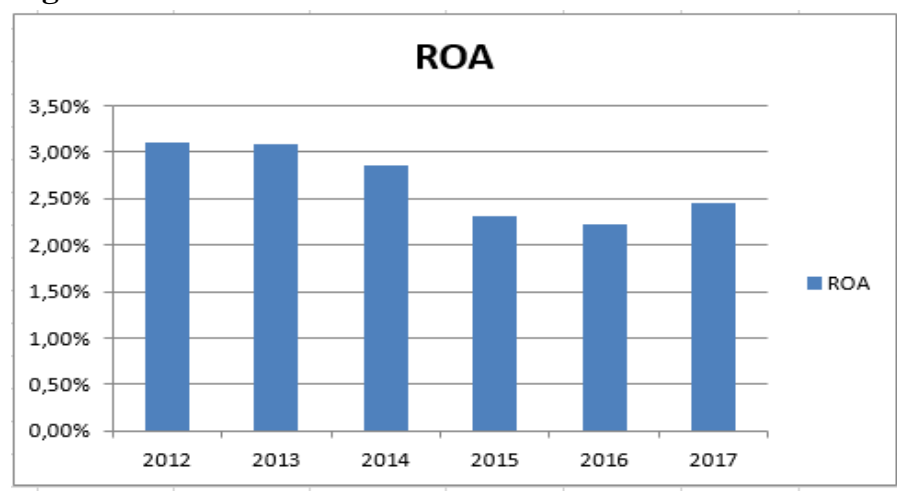

Source: Data processed by researchers (www.OJK.go.id)
But, the decline in ROA performance is not in line with the performance of loans provided by conventional banks. This is not in accordance with the theory and results of previous studies where the increase in credit provided by bank should be directly proportional to the bank's profitability(Ahmed et al. 2018). It is different from the conditions that occur, although bank's profitability in 2012 and 2017 shows a decline but the credit provided by banks in Indonesia continues to increase. As shown in figure 2 below:

Figure 2: Loans Performance of Banks in Indonesia

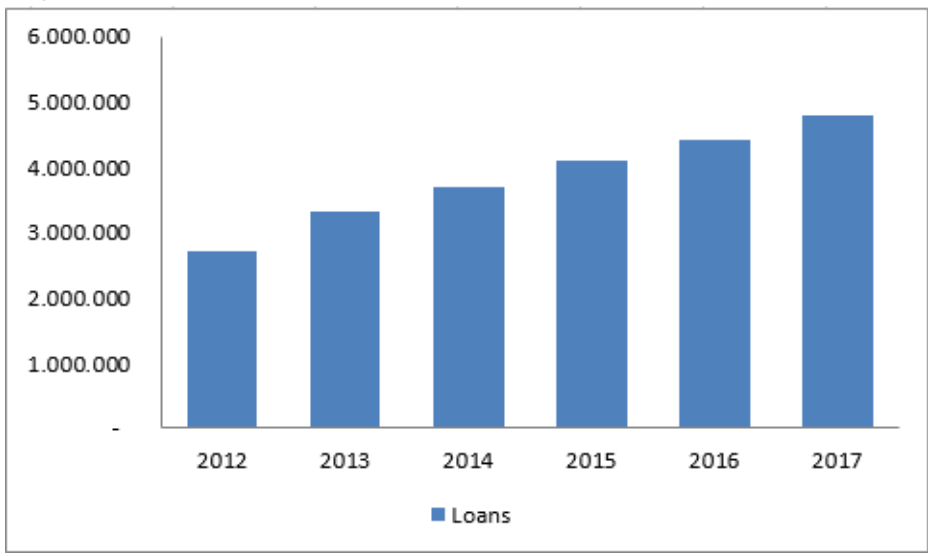

Source: Data processed by researchers (www.OJK.go.id)

Loan to Deposit Ratio (LDR) is an indicator of bank liquidity. LDR is also often used to assess the performance of loans distribution carried out by banks. The higher LDR can be interpreted as an increase in loans provided by banks. This study attempts to analyze the relationship between 
loans performance and profitability. as shown in figures 1 and 2 in the period 2012 to 2016 shows the inconsistency relationship on loans distribute by bank and bank's profitability. This can be caused by the interrupt variables that can change the interaction of loans distribute by bank against bank profitability. Non-performing loans (NPL), net interest margin (NIM) and operating expenses on operating income (OEOI) are variables that can influence bank's profitability (Puspitasari, Setiadi, and Rizkiyanti 2015), (Junaeni 2017), (Kinanti and Purwohandoko 2017). Therefore, NPL, NIM and OEOI can mediate the effect of LDR on ROA. While the Bank Indonesia Rate (BI Rate) is used as an external factor that can affect the performance of bank's profitability (Murty and Chowdary 2018), (Junaeni 2017).

As explained earlier, banks are highly regulated entities. In Indonesia, the bank's is divided based on its capital, this is known as a commercial bank based on business activities (BUKU). As a consequence, the bank's activities are limited by its capital. There are 4 criteria in determining BUKU criteria namely, 1) BUKU 1, namely banks that have core capital of less than 1 trillion, 2) BUKU 2, namely banks that have core capital of 1 trillion to 5 trillion, 3) BUKU 3 namely banks that have core capital of 5 trillion to 30 trillion, and BUKU 4 banks are banks that have more than 30 trillion core capital. The structuring of capital ownership distinguishes business activities that can be carried out by the bank. The greater the capital owned by the bank, the more banking business activities that can be managed by the bank.

This study analyzes the performance of banks by dividing bank types into two groups. The first group consists of banks classified as BUKU 1 and BUKU 2 banks. The second group consists of banks classifies as BUKU 3 and BUKU 4. This separation is carried out with assumptions because there are differences in the business activities of each bank based on BUKU 1, BUKU 2, BUKU 3 and BUKU 4. With these differences, it can be assumed that there are differences in performance between one another.

As explained earlier there is a discrepancy between loans distribute by bank and bank's profitability performance. Therefore, this study is aimed at analyzing the effect of loans distribute by bank through measurement of LDR on profitability measured by ROA. This study uses variables NIM, NPL and OEOI as moderating variables between LDR and profitability. External influences measured by the BI rate are also examined in assessing bank performance. In addition, this researcher also analyzed the difference in performance between bank tipe one (BUKU 1 and BUKU 2) and bank tipe two (BUKU 3 and BUKU 4).

\section{MATERIAL AND METHOD}

The purpose of the banking business fundamentals is to get optimal profits by providing financial services to customers.
Investors have an interest in getting profits from the bank through increasing the value of investments and dividends given from the company. The increase in investment value can be realized with an increase in bank profitability performance. Therefore, profitability performance is an important indicator and can be used by banks in order to show its performance. Based on previous research studies, there are several factors that can affect the performance of banks, namely non-performing loans (NPL), net interest margin (NIM) and operating expenses on operating income (OEOI) and external factors such as the interest rates set by Bank Indonesia.

\section{Effect of LDR on ROA}

Loan to Deposit Ratio (LDR) is a ratio that describes the level of liquidity of a bank. This ratio is calculated by comparing between loans provided by bank with third party funds owned by the bank. An increase in LDR indicates an increase of loans provided by banks(Ahmed et al. 2018). The bank's main income comes from interest on loans. The higher the loans given by bank, the more interest earned by the bank. then, It will affect the increase in profits (Ahmed et al. 2018). Therefore, an increase in LDR can increase bank profitability(Yusuf and Surjaatmadja 2018). Based on the explanation above, the following hypotheses are formulated:

$\mathrm{H}_{1}$ : Loan to deposit ratio has a significant effect on bank's return on assets.

\section{NIM's Moderating effect on the relationship between LDR and ROA}

Net interest margin (NIM) is a ratio that measures how much the difference between loan interest earned by bank with and interest expense on third party funds. The higher NIM indicates the higher range between interest income earned by bank with interest expenses. The higher NIM resulting in higher income received by the bank (Akbar 2018). As explained earlier, an increase in LDR will trigger an increase in ROA due to the higher interest income generated. This will be further strengthened when the value of the NIM gets higher, so that the profits generated will be even greater(Silaban 2017). Likewise, when the NIM is low, it will affect the relationship between LDR and ROA. Due to the smaller income margin generated. Based on the explanation, the following hypotheses are formulated:

$\mathrm{H}_{2}$ : NIM can moderate the relationship between LDR and bank's return on assets.

\section{NPL's Moderating effect on the relationship between LDR and ROA}

The increase in LDR has a role in the growth of bank profits (Poerwanti, Puspitaningrum, and Kartika 2018). But, if the loans distributed by bank has non-performing loan, the profit that will be generated will decrease. This is because, the bank must charge the non-performing loan as expenses in statemen of profit or loss. So that even though credit is 
given high, the bank's income will decrease due to the nonperforming loan. Non-performing loan (NPL) is a ratio used as a measurement of non-performing loans owned by a bank. An increase in NPL will reduce the proportion of income received by banks(Yolanda and Sumarni 2018). Therefore an increase in NPL can reduce the profitability of banks (Setiawan and Hermanto 2017). So, the profits generated from loans provided by banks can be reduced by an increase in NPL (Christaria and Kurnia 2016). So, the value of bank profitability gets smaller. Based on the explanation, the following hypotheses are formulated:

$\mathrm{H}_{3}$ : NPL can moderate the relationship between LDR and bank's return on assets.

\section{OEOI's Moderating effect on the relationship between LDR and ROA}

The ratio of operating expenses to bank operating income (OEOI) is a ratio that indicates the operational efficiency carried out by the bank. The higher the OEOI ratio indicates the unefisien of bank operational due to the higher amount of burden that must be borne by the bank. Likewise, vice versa, the lower OEOI means that there is efficiency in the bank's operating expenses. So an increase in OEOI can result in lower bank's profitability (Kusumastuti and Alam 2019). Therefore, the high value of OEOI can reduce the contribution of interest income derived from loans provided by banks. Then, it can reduce bank's profitability(Komara 2017). Based on the explanation above, the following hypotheses are formulated:

$\mathrm{H}_{4}$ : OEOI can moderate the relationship between LDR and bank's return on assets.

\section{Effect of BI Rate on ROA}

In addition to the company's fundamental factors, there are other factors that can affect the company's profitability. These factors can come from the company's external environment such as macroeconomic conditions. Based on previous research, interest rates can have more influence on profitability than other macroeconomic factors such as inflation and the rupiah exchange rate(Junaeni 2017). Banks in Indonesia follow the benchmark interest rate from Bank Indonesia. When Bank Indonesia interest rates are high, the bank will increase the interest on its loans. Increased interest loans have an impact on increasing bank profitability. Where when the interest earned by the bank is high, the bank's profit will increase automatically. Based on this explanation, the hypothesis is formulated as berkut:

$\mathrm{H}_{5}$ : BI Rate has a significant effect on bank's return on assets.

\section{RESEARCH DESIGN}

This research is quantitative research that is intended to prove the theory that has been built. The data used in this study are secondary data in the form of financial statements of banks in Indonesia from the period 2013 to 2016. The study period was chosen because in that period there was an inconsistent relationship between the increases in credit provided with a tendency to decrease bank profitability bank in Indonesia. The sample selection method used was purposive sampling. Criteria for the data taken are as follows:

1. The bank reports their financial statements continuously during the study period from 2013 to 2016.

2. The bank does not change their category from BUKU 1 and BUKU 2 to BUKU 3 or BUKU 4 during the study period.

Of the 42 banking companies listed on the Indonesia Stock Exchange only 25 banks met the sample selection criteria. Where, 16 banks did not report their financial statements consecutively during the study period. 1 banks change from BUKU 1 and BUKU 2 banks to BUKU 3 and BUKU 4 Banks. So, from the existing sample there are 12 banks categorized into BUKU 1 and BUKU 2. While as many as 13 bank sample from BUKU 3 and BUKU 4 banks.

\section{Data Analysis}

In this study the data were analyzed using descriptive and inferential statistics. Descriptive analysis uses SPSS and for hypothesis testing is conclude using AMOS software. Data were analyzed using path analysis. In path analysis, the first thing to do is to make a path analysis model(Ghozali 2014). In this case, the model used the manifest variable. The variables in this study consisted of three variables, namely the independent variable, dependent variable and moderating variable. Hypotesis testing is concluded by looking at the significance level of the influence of the independent variables on the dependent(Ghozali 2014). As well as, the significance level of the moderating variable. The results of the analysis are obtained by comparing the information obtained from descriptive and inferential analysis.

\section{Variable Measurement}

As explained earlier, this study uses three variables, namely independent, dependent and moderating variables. Following are the definition of operational variables:

Table 1

\begin{tabular}{|l|l|l|}
\hline \multicolumn{2}{|l|}{ Independent Variable } & Source \\
\hline Variable & Measurement & Total Loans Distributed by Bank \\
\hline Loan to Deposit Ratio (LDR) & Total Third Party Funds & $\begin{array}{l}\text { (Setiawan and Hermanto 2017), } \\
\text { (Hakim and Sugianto 2018). }\end{array}$ \\
\hline
\end{tabular}


"The Performance of Banks In Indonesia Based on Capital Perspective (BUKU), A case Study in a period of Decline in Profitability Performance"

\begin{tabular}{|l|c|l|}
\hline Dependent Variable & $=\frac{\text { Net Income Before Taxes }}{\text { Average Total Assets }} x 100 \%$ & $\begin{array}{l}\text { (Setiawan and Hermanto 2017), } \\
\text { (Hakim and Sugianto 2018). }\end{array}$ \\
\hline Return on Assets (ROA) & \multicolumn{2}{|l|}{} \\
\hline Variabel Moderasi & $=\frac{\text { Net interest income }}{\text { Average earning assets }} x 100 \%$ & (Setiawan and Hermanto 2017). \\
\hline Net Interest Margin (NIM) & $\frac{\text { Non-Performing Loans }}{\text { Total Loans Distributed by Bank }} x 100 \%$ & $\begin{array}{l}\text { (Setiawan and Hermanto } \\
\text { 2017),(Hakim and Sugianto 2018). }\end{array}$ \\
\hline Non-performing Loan (NPL) & $=\frac{\text { Total Operating Expenses }}{\text { Total Operating Income }} x 100 \%$ & $\begin{array}{l}\text { (Setiawan and Hermanto } \\
\text { 2017),(Hakim and Sugianto 2018). }\end{array}$ \\
\hline $\begin{array}{l}\text { Operational Expenses on } \\
\text { Operating Income (OEOI) }\end{array}$
\end{tabular}

Source: Data processed by researchers.

\section{RESULT AND DISCUSSION}

Based on the literature review and research problems and the research objectives to be discussed, the research model is formulated as follows:

Figure 3: Conceptual Framework

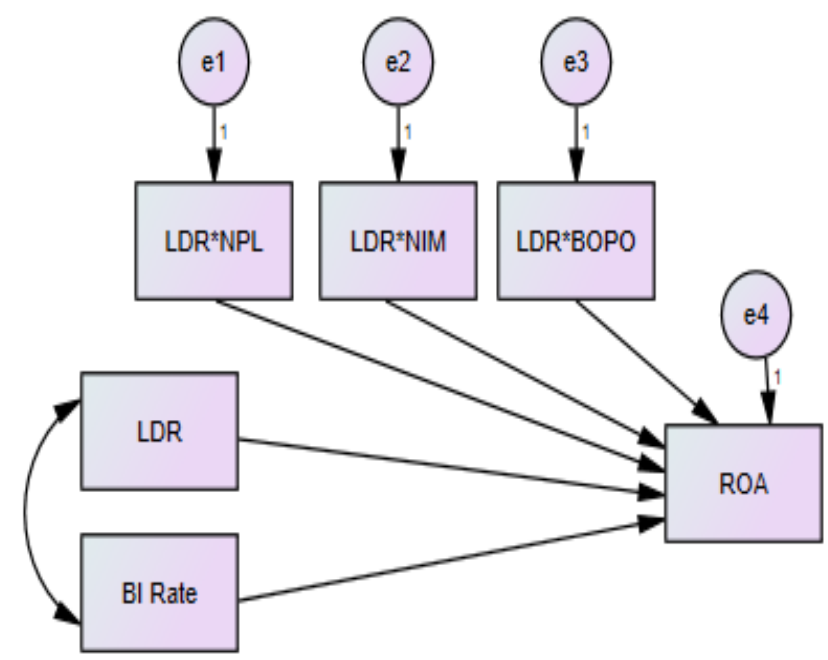

Analysis of Bank BUKU 1 and BUKU 2

Information generated from descriptive statistical analysis on 12 banks categorized into BUKU 1 and BUKU 2 during the period of 2013 to 2016 are as follows:

Table 2: Descriptive Statistics of Bank BUKU 1 and BUKU 2

\begin{tabular}{|c|c|c|c|c|}
\hline & $\mathrm{N}$ & Minimum & Maximum & Mean \\
\hline LDR & 48 & .551 & 2.096 & .87775 \\
NIM & 48 & .013 & .199 & .04270 \\
NPL & 48 & .002 & .167 & .04773 \\
OEOI & 48 & .328 & 1.632 & .83756 \\
BI Rate & 48 & 4.47 & 7.75 & 6.8050 \\
ROA & 48 & -.111 & .039 & .00377 \\
\hline
\end{tabular}

Source: Data processed by researchers.

Information obtained from inferential statistics on the research hypothesis testing of 12 banks categorized into BUKU 1 and BUKU 2 during the period of 2013 to 2016 are as follows:

Source: Data processed by researchers.

Table 3: Inferential Statistics of BUKU 1 and BUKU 2

\begin{tabular}{|lll|ccccc|}
\hline & & & Estimate & S.E. & C.R. & P & Label \\
\hline ROA & $<---$ & LDR &, 040 &, 013 & 2,990 &, 003 \\
ROA & $<---$ & BIRate &, 006 &, 002 & 2,603 &, 009 \\
ROA & $<---$ & LDRxNPL &, 090 &, 066 & 1,369 &, 171 \\
ROA & $<---$ & LDRxNIM &, 128 &, 116 & 1,105 &, 269 \\
ROA & $<---$ & LDRxOEOI &,- 069 &, 013 & $-5,502$ & $* * *$ \\
\hline
\end{tabular}

Source: Data processed by researchers.

The results of the descriptive analysis in table 2 show that the LDR value of the average bank is high at $88.77 \%$. Table 3 shows that in BUKU 1 and BUKU 2 banks LDR has a significant influence on bank's profitability. This result 1968 means that the increase in ROA of BUKU 1 and BUKU 2 banks is influenced by the LDR. In line with previous studies which stated that an increase in LDR led to an increase in bank's ROA (Yusuf and Surjaatmadja 2018). 
Table 3 also shows that the BI Rate affects the performance of bank profitability. It means that the more reference interest rates set by Bank Indonesia have an impact on increasing the profitability of BUKU 1 and BUKU 2 banks. In line with previous research where an increase in the BI rate has a positive effect on bank's profitability(Ahmed et al. 2018). However, the increase in LDR and BUKU 1 and BUKU 2 bank interest rates is mediated by the inefficiency of bank operations. Evidenced by the high value of OEOI resulted in decreased profitability. This answers the research question where credit is not in line with bank profitability. The low profitability of banks during the study period is influenced by an increase in OEOI (Wulandari, Anggraeni, and Andati 2018).

The results of this study do not support the hypothesis which states that NPL and NIM can mediate the effect of LDR on ROA. It is because the value of NPL of banks observed is small, which is an average of $4.8 \%$. So, an increase in NPL does not affect ROA (Kusumastuti and Alam 2019). In table 4 we can see that NIM cannot mediate the effect of LDR on ROA. In contrast to previous studies where an increase in NIM influenced the increase in ROA (Watuseke, Worang, and Tielung 2019).

\section{Analysis of Bank BUKU 1 and BUKU 2}

Information generated from descriptive statistical analysis on 13 banks categorized into BUKU 3 and BUKU 4 during the period of 2013 to 2016 are as follows:

Table 4: Descriptive Statistics of Bank BUKU 3 and BUKU 4

\begin{tabular}{|l|l|l|l|l|}
\hline & $\mathrm{N}$ & Minimum & Maximum & Mean \\
\hline LDR & 52 & .534 & 1.327 & .90199 \\
NIM & 52 & .032 & .116 & .05886 \\
NPL & 52 & .007 & .159 & .04809 \\
OEOI & 52 & .410 & .867 & .70204 \\
BI Rate & 52 & 4.47 & 7.75 & 6.8050 \\
ROA & 52 & -.050 & .047 & .02230 \\
\hline
\end{tabular}

Source: Data processed by researchers.

The Information obtained from inferential statistics on the research hypothesis testing of 13 banks categorized into BUKU 3 and BUKU 4 during the period of 2013 to 2016 are as follows:

Table 5: Inferential Statistics of BUKU 3 and BUKU 4

\begin{tabular}{|lll|ccccc|}
\hline & & & Estimate & S.E. & C.R. & P & Label \\
\hline ROA & $<---$ & LDR &, 014 &, 011 & 1,266 &, 205 & par_1 \\
ROA & $<--$ & BIRate &, 002 &, 001 & 1,896 &, 058 & par_5 \\
ROA & $<--$ & LDRxNPL &,- 091 &, 053 & $-1,716$ &, 086 & par_2 \\
ROA & $<--$ & LDRxNIM &, 371 &, 077 & 4,843 & $* * *$ & par_3 \\
ROA & $<---$ & LDRxOEOI &,- 058 &, 010 & $-5,691$ & $* * *$ & par_4 \\
\hline
\end{tabular}

Source: Data processed by researchers.

Unlike the BUKU 1 and BUKU 2 banks, the profitability of BUKU 3 and BUKU 4 banks is not affected by the LDR and $\mathrm{BI}$ rate. BUKU 3 and BUKU 4 banks have better profitability performance compared to BUKU 1 and BUKU 2 banks. This can be seen from the difference in ROA values shown in tables 2 and 4 . The average profitability of BUKU 3 and BUKU 4 banks is $2 \%$ while the average of ROA in BUKU 1 and BUKU 2 banks is worth $0.3 \%$. This shows that the profitability of BUKU 3 and BUKU 4 banks is better. Therefore, the interest rate does not significantly influence ROA. In line with previous researchers, where the BI rate does not have a significant effect on ROA (Ali et al. 2018). Although on average the performance of BUKU 3 and BUKU 4 banks is better, but the value of BUKU 3 and BUKU 4 NIM is also better than the value of bank NIM BUKU 1 and BUKU 2. Therefore, NIM more influences the profitability of BUKU 3 banks and BUKU 4 of the contributions given by the LDR. In line with previous research where the high value of NIM is directly proportional to the high value of bank ROA (Setiawan and Hermanto 2017). Therefore, NIM can mediate the effect of LDR on ROA of BUKU 3 and BUKU 4 banks.

However, although the proportion of bank income in BUKU 3 and BUKU 4 is high due to the high value of NIM. However, the value of OEOI is also high, so the net profit obtained by the bank BUKU 3 and BUKU 4 is not too high. In line with previous research, where an increase in OEOI can reduce the value of profitability (Wulandari et al. 2018). This answers the research problem where the role of LDR in contributing to the ROA of BUKU 3 and BUKU 4 banks is mediated by NIM and OEOI. While, the NPL does not mediate the effect of LDR on ROA because the value of non-performing loans owned by banks is small. So that NPL does not have a significant impact on profitability 
"The Performance of Banks In Indonesia Based on Capital Perspective (BUKU), A case Study in a period of Decline in Profitability Performance"

(Permatasari and Amboningtyas 2017). Therefore, NPL cannot mediate the relationship of LDR to ROA.

\section{CONCLUSION}

Based on the results of the research analysis, it can be concluded that there are differences in performance between the first category banks (BUKU 1 and BUKU 2 banks) and the second category banks (BUKU 3 and BUKU 4 banks). The profitability performance of BUKU 1 and BUKU 2 banks is influenced by the LDR and BI rate. The variable that mediates LDR to ROA of BUKU 1 and BUKU 2 banks is OEOI. While the LDR and BI rate at BUKU 3 and BUKU 4 banks have no significant impact on profitability. Variables that mediate LDR to ROA of BUKU 3 and BUKU 4 banks are NIM and OEOI.

The level of efficiency BUKU 1 and BUKU 2 banks must be considered. Because based on the analysis that there is efficiency is the cause of the low value of ROA. As with BUKU 1 and BUKU 2 banks, the efficiency of BUKU 3 and BUKU 4 banks also caused profitability performance to be poor. Although, the performance of lending and bank NIM BUKU 3 and BUKU 4 are good, the resulting profit can be reduced due to inefficient operating performance.This study also supports the statement that macroeconomic factor such as $\mathrm{BI}$ rate tend to influence BUKU 1 and BUKU 2 banks than BUKU 3 and BUKU 4 banks.

\section{REFERENCES}

1. Ahmed, Afzal, Raja Rehan, Imran Umer Chhapra, and Saima Supro. 2018. "Interest Rate and Financial Performance of Banks in Pakistan." International Journal of Applied Economics, Finance Adn Accounting 2(1):1-7.

2. Akbar, Taufiq. 2018. "DETERMINATION OF BANK PROFITABILITY WITH EFFICIENCY AS." International Journal of Economics, Business and Management Research 2(6):51-59.

3. Ali, Akbar, Amir Amri, Delis Arman, and Machudin Asep. 2018. "Effect of Monetary Variables on Conventional Bank Performance and Sharia Banks in Indonesia, 2010-201.” Russian Journal of Agriculture and Social-Economic Scinces 1(73):8691.

4. Christaria, Fiola and Ratnawati Kurnia. 2016. "The Impact of Financial Ratios , Operational Efficiency and Non- Performing Loan Towards Commercial Bank Profitability." Accounting and Finance Review 1(1):43-50.

5. Ghozali, Imam. 2014. Model Persamaan Struktural Konsep Dan Aplikasi Dengan Program AMOS 22.0. Semarang: Badan Penerbit - UNDIP.

6. Hakim, Luqman and Sugianto. 2018. "Determinant Profitability and Implications on the Value of the Company: Empirical Study on Banking Industry in
IDX." International Journal of Economics and Finance 8(1):205-16.

7. Junaeni, Irawati. 2017. "Dominant Variables That Affect The Level of Profitability in Sharia Banks and Conventional Banks.” 3(2):126-35.

8. Kinanti, Risma Ayu and Purwohandoko. 2017. "Influence of Third-Party Funds, CAR, NPF Adn FDR towards The Return on Assets of Islamic Banks in Indonesia." Jurnal Ilmiah Bidang Akuntansi Dan Manajemen 14(2):135-43.

9. Komara, Edi. 2017. "Influence of Bank Health Ratio on Financial Performance of Islamic Commercial Bank." Jurnal Ilmu Manajemen \& Ekonomika 1(6):1-6.

10. Kusumastuti, Wahyu Intan and Azhar Alam. 2019. "ANALYSIS OF IMPACT OF CAR, BOPO, NPF ON PROFITABILITY OF ISLAMIC BANKS." 2(1):30-59.

11. Murty, A. V. N. and E.Roshma Chowdary. 2018. "Effective of Interest Rates Changes on Profitability of Banking Industry in India ( An Empirical Research on the Profitability Performance of Nationalized Banks in India )." Journal of Business and Management 20(2):82-91.

12. Permatasari, Anita Karina Mastika and Dheasey Amboningtyas. 2017. "The Influence of Ldr, DPK, and NPL on ROA through CAR as Intervening Variable (Study on Conventional Bank Sub Sector Company 2012-2016 Listed in BEI)." Journal of Management 3(3):2-7.

13. Poerwanti, R., Titis Puspitaningrum, and Dewi Kartika. 2018. "The Effect Of CAR , NPL \& LDR On The Profit Improvement Of Regional Development Bank In Indonesia By Using Credit Growth As Intervening Variable ( Research on Regional Development Banks in Java , Bali \& NTT ) Period 2011 - 2015.” 1(2):188-202.

14. Puspitasari, Devy M., Nugroho J. Setiadi, and Nurrina Rizkiyanti. 2015. "Implementation of The Indonesian Banking Architecture as A Blueprint of The Direction and Order of The National Banking System: Empirical Study of Indonesia Commercial Banking." The Winners 16(1):6-14.

15. Setiawan, Andy and Bambang Hermanto. 2017. “COMPARATIVE STUDY : DETERMINANT ON BANKING PROFITABILITY BETWEEN BUKU 4 AND BUKU 3 BANK IN INDONESIA.” BENEFIT Jurnal Manajemen Dan Bisnis 2(1):92-101.

16. Silaban, Pasaman. 2017. "The Effect of Capital Adequacy Ratio, Net Interest Margin and NonPerforming Loans on Bank Profitability : The Case of Indonesia." International Journal of Economics and Business Administration 5(3):58-69.

17. Watuseke, Christiadi, Frederik G. Worang, and 
"The Performance of Banks In Indonesia Based on Capital Perspective (BUKU), A case Study in a period of Decline in Profitability Performance"

Maria V. J. Tielung. 2019. "Determinants of Bank Profitability in Indonesia (Case Study on Indonesia Commercial Banks Listed in IDX Periode 20102015)." Jurnal EMBA 7(1):211-20.

18. Wulandari, Tri, Lukytawati Anggraeni, and Trias Andati. 2018. "Economic Journal of Emerging Markets." 8(14):109-19.

19. Yolanda and Sumarni. 2018. "Financial Performance and Factors Influencing Banking Companies in Indonesia Stock Exchange." Russian Journal of Agriculture and Social-Economic Scinces 3(75):6372.

20. Yusuf, Muhammad and Surachman Surjaatmadja. 2018. "Analysis of Financial Performance on Profitability with Non Performance Financing as Variable Moderation ( Study at Sharia Commercial Bank in Indonesia Period 2012 - 2016 )." 8(4):12632. 